\title{
Levantine Polities under Mittanian Hegemony
}

By the time Mittani emerges into the light of history - that is, the available written sources it is a fully formed kingdom in possession of an empire. We can glimpse a few moments of its expansion: toward the mid-I5th century, for example, Mittani acquired suzerainty over Alalakh and then Kizzuwatna, presumably adding these two realms to an existing stock of vassal states. Somewhat earlier, Egyptian armies under Amenhotep I (or perhaps his successor Thutmose I) encountered Mittani for the first time, evidently as a regional hegemon if not already an imperial power. And Old Hittite sources permit peering back in time to the kingdom's infancy in the early i6th century, before it acquired either the name Mittani or an empire. Compiling all references to Mittani (or proto-Mittani), under this designation or others, suffices to produce a general outline of the kingdom and its history. ${ }^{\mathrm{I}}$ But the events and processes through which the polity called Mittani came into being, grew, and governed are, to date, illuminated by scarcely a scrap of direct evidence. Not only have we no archives or royal inscriptions from Mittani itself - only a handful of letters and documents issued thence that were found in their addressees' archives - we have no legends of its founding kings as we do for the empire of Akkad, nor have we any other sort of literary testimony, such as that which re-copied royal hymns and letters provide for the kings of Ur. By the time the sources become sufficient in number and variety to produce a reasonably detailed portrait of Mittani, it is an empire in the agony of demise. This state of affairs is not Mittani's fault - its scribes valiantly adapted cuneiform to write Hurrian with greater phonological precision than the Akkadian and Sumerian they also employed in writing; but most of the records they must once have produced have either failed to survive or eluded discovery. It is just bad luck, Mittani's and ours.

We are thus thrown back on the evidence of records kept or produced by those with whom Mittani interacted. Here it should be noted that we call the entity under discussion Mittani not because it was usually called by that name in its own day, but because we find it convenient to use a single unambiguous designation for the polity also known as Hanigalbat, whose king was "king of the Hurrian troops", and whose country also received the

\footnotetext{
* University of Minnesota. I am grateful to the other workshop participants for their contributions to the discussion, as well as for remarks on sources pertinent to my own theme which I had overlooked.

I For such an outline, from the perspective of Alalakh, see von Dassow 2008, I2-64, esp. I9-23. From a broader perspective, Giorgieri (2005) offers a selective overview treating the structure of Mittani's political hegemony and the cultural influence exercised by Mittani upon the regions under its sway.
} 
West Semitic designation Naharina (var. Nahrima), "river-land” (or "rivers twain”), which was preferred in Egypt. ${ }^{2}$

In the present paper I discuss the shape, structure, and dynamics of Mittani's empire in the Levant, and of the polities under its rule. This involves addressing questions such as how Mittani acquired hegemony over Levantine kingdoms, how it governed them, and how those realms responded to Mittanian rule. (It should also involve Mittani's interaction with Levantine kingdoms it did not rule, which however is not encompassed in the present paper.) The largest number of textual sources that bear directly on such questions derives from I5th-century Alalakh. These may be supplemented by sources from Arraphe on the opposite side of the empire, while various other sites or text corpora yield somewhat less, or less useful, material. Within Mittani's domain, this material includes one or more tablets apiece from Terqa, Tall Bazi, Tall Brak (ancient Nagar), Umm el-Marra, and Emar; beyond the empire's periphery, the archives of Hattuša, Egyptian texts, and the Amarna correspondence contribute perspectives, data, and soundbites. ${ }^{3}$

This body of evidence, which has grown but incrementally over the course of the last century, discloses so little information about the Mittani Empire that the resulting vacuum attracts specious modes of explanation. Two interconnected approaches to the study of Mittani are to be excluded at the outset: I) explaining the kingdom's origins and successful growth by reference to the arrival of a new population, specifically, an Aryan one; and 2) explaining these phenomena by reference to the development of a new military technology, namely horse-drawn chariotry. Having addressed both issues in extenso elsewhere, 4 I shall merely summarize them here.

I. The kingdom called Mittani was not the creation of an Aryan population newly arrived in southwestern Asia. A tiny quantity of Indo-Aryan vocabulary and proper nouns became incorporated into the Hurrian language of Mittani, while also spreading among realms with which Mittani interacted, over the course of the empire's floruit. 5 Apparently no one in Mittani spoke the Indo-Aryan source language, for the borrowed lexical items were unproductive in the borrowing language, there is no Indo-Aryan grammatical interference therein, and no other extant evidence indicates that the donor language had ever been the

2 Recently Valério (20II) has argued for reading Hani-GAL-bat as Hani-rabbat, which he would interpret as "Great Hani" and relate to the designation Hana, denoting mobile pastoralists and the land they occupied. Addressing his arguments in full will have to await another occasion; for the nonce, suffice it to note that spellings with $\mathrm{GAL}_{9}$ occur in three different archives (ibid.: I78), a distribution that cannot be explained as the outcome of scribal misapprehension or error.

3 To this list should be added the five-line letter found at Tell Hammām et-Turkmān and dated c. I500, assuming that it was indeed sent by a king of Mittani (van Soldt I995: 277-278). The letter, a concise directive from "the king" to one Šatuwatri that one Karukka(ma) should come quickly, is so laconic that it contributes virtually no historical information beyond its existence and findspot.

4 von Dassow 2008, 77-90.

5 The much tinier quantity of Indo-Aryan lexical material that entered Kassite, perhaps independently, is left aside in the present context. 
living cultural property of any part of the kingdom's population. The scant Indo-Aryan linguistic material does not attest the presence, much less the dominance, of an Indo-Aryanspeaking population. Instead, the kingdom's identity was "Hurrian", as attested by numerous references to the king of Mittani as "king of Hurri(-land)" or "king of the Hurrian troops" (not "king of the Aryan troops" or the like). While the practice of bestowing throne names of Indo-Aryan derivation on most of Mittani's kings suggests significant contact with an Indo-Aryan-speaking population, it does not indicate that the royal dynasty (much less the ruling class) was of Aryan "blood" - whatever that might mean.

2. Mittani's success did not result from the innovation of using horse-drawn chariots in war, or in any case, this innovation did not belong to Mittani. The development of chariotry was shared by the kingdom's contemporaries and opponents, and the evidence does not suggest that it originated among the polities or peoples antecedent to Mittani. ${ }^{6}$ Though military success must have been essential to the foundation and growth of Mittani, military innovation was not.

Hence, no special role can be attributed to the social class associated with chariotry and denoted by the Hurrianized Indo-Aryan word maryanni (on this class, see further below). The formation of this class was moreover posterior to the formation of Mittani; it was not a cause of the empire's creation but an effect thereof.7

6 Against the view that the chariot was invented within the Near East during the early second millennium BC, continuing the long indigenous development of equid-drawn wheeled vehicles (Raulwing 2000, esp. 59. 99, with exhaustive references to previous literature), David Anthony presents a convincing argument for the invention of the chariot in the Eurasian steppe, specifically in the region of the Sintashta culture just east of the Ural Mountains, during the last century of the third millennium BC (Anthony 2007, esp. ch. I5). The chariot is defined as a two-wheeled vehicle having spoked wheels and drawn by bitted horses, controlled by a standing driver (see ibid. 397; similarly Raulwing 2000,43 ). Anthony argues that the key innovations, bits and spoked wheels, appeared centuries earlier in the steppe than in the Near East, according to the evidence of well-dated finds at Sintashta and related sites. He further marshals evidence that the chariots of the steppe were indeed made and used for war (not merely ceremony or display; Anthony 2007, 399-405); makes a persuasive case (despite a proclivity for overinterpreting the evidence in accord with the model, and for a high dating of the Rg Veda and Avesta) that the makers of these chariots probably spoke an Indo-Iranian language and may even have identified themselves as "Aryans" in the Vedic sense (ibid.: 405-4II); and proposes a historico-geographical pathway through which the innovation of chariotry, the requisite horses, and the accompanying Indo-Iranian vocabulary could have entered southwestern Asia from the Eurasian steppe (ch. I6, esp. 42I-427 and 452-457). But none of this, however true, validates the clichéd notions Anthony recycles about Mittani (which - repeating a common error - he mistakes for a people) and its origins. No matter where chariots were invented and what language their makers spoke, claims like "an Old Indic-speaking group of chariot warriors took control of a Hurrian-speaking kingdom in north Syria about 1500 BCE" and "the Mitanni dynasts came from the same ethnolinguistic population as the more famous Old Indic-speakers who simultaneously pushed eastward into the Punjab" (ibid., 454) remain, at best, unfounded.

7 The validity of these statements is not materially affected by the aberrantly early attestation of "maryanni troops" in a tablet from Tall Leilan (L.87-887), disclosed by Jesper Eidem in his paper for the present workshop (see below, p. I42 with n. I6). Assuming not only that the reading is correct but that it does in fact attest the Hurrianized Indo-Aryan word maryanni, not some homophone, this occurrence of the term predates any other by a couple of centuries even on the lowest chronology. While the appearance of troops denoted maryanni in the Old Babylonian period begs for explanation, it does not warrant assuming the existence of a social class denoted maryanni (nor can 
To fill in the information vacuum by positing an invasion of chariot-riding Aryans, or the like, is an exercise in pseudo-historical wish fulfillment, not historical explanation. Incidentally, no more can the rise of Mittani be accounted for by the expansion and dominance of Hurrians (or Hurrian-speaking people) than by the imaginary Indo-Aryan takeover. The mode of explanation whereby historical change is supposed to result from movements of peoples remains as popular as it is simplistic. People do move, sometimes in groups, and sometimes as members of an "ethnic" group, but seldom is such movement the predominant factor in causing historical change. The like can be said of attributing a causal role to the introduction of new military technology (which, incidentally, never remains the property of a single population group for long): the new technology operates as a factor only in association with the factors that promoted its own development. In the case at hand, explanations of these types are neither supported by the evidence, nor do they provide a plausible or sufficient account of it.

While invoking a deus ex machina - like a spurious population influx - is not a valid historical method, the work of history does require going beyond merely accumulating and paraphrasing evidence that bears on the problem at issue. That is, although collecting the pertinent sources and data remains a prerequisite for the inquiry at hand, methods of inference are necessary to develop a theory that can account for the observable data while going some way toward elucidating the structure and governance of Mittani's empire. In what follows, therefore, besides cataloguing sources and their contents I shall explore synthetic approaches that may help outline a model of Mittanian rule.

\section{The political landscape}

The geographical reach of Mittani's rule can be roughly plotted on the basis of the available sources. Its empire extended east to the land of Arraphe, north to the latitude of Lake Van, south to Terqa, and west across the lands formerly subject to Halab (without, however, automatically including Emar and Aštata); for a time, it extended as far west as Kizzuwatna and as far south as Tunip or even beyond (before one and then another kingdom was lost to Hatti). ${ }^{8}$ Our modern habit is to extrapolate contiguous territorial control from such data points and to color in the map so that the empire encompasses those points. However, the effective control of even the most powerful Late Bronze Age polity generally did not reach far beyond the hinterland of settlements and, on a good day, the routes that linked them. Therefore the map of Mittani's empire should instead be visualized as a network of points

such a class be considered an element of "Hurrian social structure", pace Eidem; were it so, such a class would have existed before Hurrian speakers ever borrowed the Indo-Aryan word márya to give it a new name).

8 Tunip's play for Egypt's attention in EA 59, with its claim to have been subordinate to Egypt in the past, selects elements of its history to make an argument that in the long run failed. 
of control, each point the seat of a kingdom or province and each situated within its own cluster of points; the space between or beyond these linked nodes can scarcely be counted for the domain of Mittani or any other territorial state.9 (Later, the Hittite kingdom succeeded to some extent in changing this model of the political landscape.)

\subsection{Vassal kingdoms: the example of Alalakh}

What kind of control did Mittani exercise over the polities subject to its hegemony? What was the structure of governance, and what were the mechanisms through which Mittani ruled? The textual records from different sites suggest diverse answers, indicating that a single model did not apply throughout the empire. I shall take Alalakh as a point of departure for examining these issues, since Alalakh yields the largest number and variety of pertinent texts (which do not amount to a great many). It will be useful to begin by itemizing these sources, although most of them have received ample scholarly attention before; the list that follows summarizes their content so far as it relates to the matter at hand. ${ }^{\circ}$

- Two parity treaties: AlT 3, between Idrimi of Alalakh and Pilliya of Kizzuwatna, and AlT 2, between Niqmepa of Alalakh and Ir-Teššub of Tunip. AlT 3, an agreement on the mutual extradition of fugitives that is formulated entirely in reciprocal terms, was concluded between the parties under the authority of Parrattarna, king of Mittani. AlT 2 is a more comprehensive agreement, formulated from the standpoint of each party addressing the other, that addresses various issues involving movement of people and accountability between the two realms; it was concluded under the authority of the "king of the Hurrian troops", overlord of both parties, and was void if either broke faith with their lord.

- Two records of legal decisions by Sauštatar, king of Mittani, in favor of Niqmepa: AlT i3, which denies the claim of a subject of Alalakh to Hanigalbatean status (discussed further below under "Sociopolitical organization", p. 22-28); and AlT i4, which vindicates Niqmepa's claim to the town of Alawari against Sunaššura of Kizzuwatna.

9 I have previously made this point in discussing the geography of Alalakh's realm (von Dassow 2008, 64-67). Later, Casana argued for a similar view of the political geography of Late Bronze Age states, including Alalakh, in an article published in February 2009 that fails to make any reference to my 2008 book, relying instead on a few pages of my 1997 dissertation. Casana pushes the argument too far, while ignoring the majority of the pertinent textual evidence (as well as pertinent scholarship), when he asserts that since a polity was not constituted by contiguous territory but by its "ownership" of particular towns, a given town belonging to a given polity could be "anywhere" (Casana 2009, 25).

Io Fuller discussion of each text, with references to previous literature, may be found by consulting the index of sources in von Dassow 2008, 543-55I. Two of these texts, AlT i3 and I4, have now been reedited by Niedorf (2008, 239-247; in his numbering they are Texts 3I.I and 3I.2), who also treats each of the other Alalañ texts discussed here, in greater or lesser detail. 
- $\quad$ Four letters conveying orders on the authority of "the king" (of Mittani). Three are letters from Tiriș-ra, evidently a Mittanian official, to Niqmepa: in AlT ııo, Tiriṣ-ra instructs Niqmepa to seize some men and have them brought to him; AlT III concerns a certain man's movable property and the provision of an escort for him; and in AlT II2, Tiris-ra informs Niqmepa that a lawsuit before the king has been decided against him, and orders Niqmepa to give the plaintiff the women he sued for. ${ }^{\text {II }}$ Another letter, AlT Io8, is addressed by the king to one Utti, and orders him to release toll-free the asses Niqmepa had complained about; presumably Utti ruled a neighboring realm, and this tablet ended up in Niqmepa's archive because he was the beneficiary of the decision it

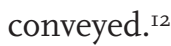

- Two administrative records refer to Mittani, unfortunately without contextual information adequate to tell this reader what is going on. AlT 224 lists numbers of men in association with particular towns within Alalakh's realm under the heading "these men are going to the land of Mittani"; after a break the list continues recording numbers of men in association with more towns, the palace, tasks or purposes, Mittani, and individuals, including Tiriș-ra. ${ }^{\mathrm{I3}}$ AlT 340, a more laconically opaque text, records nine oxherds in some relation to "the land of Hurri", presumably meaning Mittani (whether the herdsmen or their oxen may be going or coming is not clear). ${ }^{\mathrm{I}} 4$

II Niedorf (2008, 4I) infers that the plaintiff in AlT II2 (his Text 2.9), Arip-šanihu, must be either a vassal (like Niqmepa) or a subject directly subordinate to the Mittanian king. However, Arip-šanihu need no more be a Mittanian vassal or subject than Irip-Hazi, the plaintiff of AlT I3 (see above; and Niedorf 2008, 24I), in order to sue Niqmepa before the king of Mittani.

I2 Although the seal impressed on AlT ro8 is not identifiable as that of a king of Mittani, and moreover Utti is otherwise unknown (he can hardly be identical to Utti, the co-seller of a woman in AlT 67), no other king in a position to give orders affecting Niqmepa could have been identified simply as "king" with no indication of his name or realm. Cf. Niedorf 2008, 39 (Text 2.5 = AlT I08), with n. I44.

I3 One difficulty in understanding AlT 224 lies in the text's use of the preposition ana ("to/for" in normal Akkadian usage): the men "going to (ana) Mittani" are recorded as 5 men ana town A, 5 men ana town B, and so forth (likewise on the reverse, which may have its own heading). As ana is sometimes used in the meaning of ina, "from," in texts from Alalakh and elsewhere in the Levant (reflecting the usage of West Semitic $l$-), it could be so used in AlT 224, which would then record men "from (ana)" individual towns and going "to (ana)" Mittani; but that interpretation cannot be carried through consistently on the reverse. On the use of ana for ina at Alalakh, see Márquez Rowe I998, 74, who suggests that Hurrian rather than West Semitic substrate influence may account for the "indiscriminate" use of these prepositions. AlT 224 (= Text 4I6.I) is briefly treated in Niedorf 2008, 83, with n. 316.

I4 In AlT 340 (not discussed in von Dassow 2008; Text 4I5.I8 in Niedorf 2008), three entries of unclear structure are summed up as "9 oxherds, KUR Hur-ri ŠUB-ti" (or conceivably "9 herdsmen whose oxen KUR Hur-ri ŠUB-ti"); if ŠUB-ti stands for a verbal adjective, it is not obvious which verb in what meaning is intended. Niedorf reads instead KUR Har-ri-ru-ti (1998, 527; 1999, 89I; 2008, 8I), but this seems unlikely, such a land being otherwise unattested. In the Alalakh tablets, Hurri also appears in a list of garments, AlT 4I6, where certain garments are qualified as "(of the) land of Arraphe" (1. 3), "Hurrian" (Hur-ri, with no KUR determinative, 11. 5, 30), or "Subarean” (ŠU.BIR, also without KUR, 1. 7). As Zaccagnini observed (I979, 7), to distinguish between Hurri and a subordinate realm would indicate that the former refers to Mittani. 
- Finally, the inscription on the statue of Idrimi relates how Idrimi came to accept the suzerainty of Parrattarna, "king of the Hurrian troops", in order to secure his position as king of Alalakh. ${ }^{15}$

And those are all the texts among the published material from the site of Alalakh that yield direct evidence concerning Alalakh's relations with Mittani.

From this slender body of evidence scholars have often concluded that Mittani imposed only light control over the kingdoms it ruled, permitting them to carry on their own conflicts and foreign affairs as they pleased provided they did not depart the empire's fold. ${ }^{16}$ That is a curious assessment. At Alalakh we see lawsuits over the citizenship of individuals, the allegiance of towns, interstate tolls, and individuals' claims to persons and property being decided by the king of Mittani. This indicates not only that Mittani exercised both broad and specific powers over its subject states, but that local and imperial affairs were highly integrated. That conclusion is supported by the rather more ample evidence from Arraphe, Mittani's easternmost subject kingdom, whose differing geographic situation does not make it irrelevant to the western half of the empire. Texts from Nuzi and Kirkuk attest close judicial and military cooperation between Arraphe and Hanigalbat (= Mittani), as well as a variety of social and economic linkages. ${ }^{17}$ The king of Mittani could also intervene in Arraphe's territorial organization by reallocating towns from one grantee to another, as attested by HSS IX I. ${ }^{I 8}$ Meanwhile, Emar has yielded the only sources known to date that refer to tribute required from a subject polity by (apparently) Mittani. Four documents reflect the demand of tribute (arana) on two occasions, one each during the reigns of two successive rulers of Emar's "First Dynasty", the tribute recorded was heavy, and city property

I5 On the historical interpretation of the inscription of Idrimi, see von Dassow 2008, 23-45. The archaeological context of Idrimi's statue, which bears on its historical interpretation, has lately been investigated by Fink (2007; 20I0), whose examination of the evidence yields the result that the statue's findspot was not in the penultimate level of Alalakh, as Woolley had determined upon the close of the I939 season, but in the last phase of Level IV. See esp. Fink 2007, I95-199; 2010, 27-30 and 56-60.

I6 See, e.g., Drower's statement that Mittani's "vassals were held on a loose rein" (1973, 436); similarly Van De Mieroop, "The Mittani state seems to have been a loose political structure ... There was thus probably little influence on the local affairs" (2007, I54). Such assessments do not reflect thorough consideration of the available evidence, little as it is.

I7 The evidence for relations between Arraphe and its overlord was collected by Zaccagnini (I979; though most of the texts come from Nuzi, Arraphe is really the focus of discussion). Particularly relevant here are Zaccagnini's remarks on coordination between the courts (Zaccagnini I979, I0) and the military forces (ibid., 20-25) of Arraphe and Hanigalbat. The pertinent sources have lately been augmented by Lion's publication of a tablet in the Louvre (AO I555I+I5552) that records the reconstruction of Nuzi's fortifications, and mentions that men of Hanigalbat had participated in building them (Lion 2010).

I8 This text is the famous "Sauštatar letter", addressed to Ithi-Teššub (Ithiya), king of Arraphe, by one of Sauštatar's successors who used his seal; for a translation, with brief discussion, see Wilhelm 200I, IoIf. The town that was the object of reallocation had been granted to ${ }^{\mathrm{f} A m m i n a y a, ~ c o n s o r t ~ o f ~ t h e ~ c r o w n ~ p r i n c e, ~ w h i c h ~ l i m i t s ~ t h e ~ w a r-~}$ rant for extrapolating from this transaction: one cannot assume that the king of Mittani could similarly appropriate and redistribute the property of every Arraphean subject. 
had to be sold to collect the funds to pay it.19 Whether such tribute payments were exceptional or regular, and on what schedule they might have been demanded, cannot however be inferred from this limited documentation. ${ }^{\circ}$

That we are not better informed about what support Mittani's vassals were required to provide their overlord may be accounted a deficiency in the surviving sources, not a deficiency in the empire's capacity to command resources. Egyptian records, notably the inscriptions of Thutmose III, attest that Mittani (a.k.a. Naharin) could and did summon the Levantine kingdoms under its rule to war. ${ }^{2 \mathrm{I}}$

\subsection{Other polities}

The realms of Alalakh, Arraphe, Kizzuwatna, and Tunip, among others, were each ruled by their own kings under the overlordship of Mittani. Not every polity within the empire possessed a king, however, and the hierarchical relationship linking local monarch to great king did not take the same form in every polity that did. Models of governance that differ from the lord-vassal dyad are evident in the records pertaining to Halab, Tall Bazi, and Terqa.

Among the tablets found at Terqa are several contracts, mostly unpublished, in which the local king is named alongside the Mittanian king. ${ }^{22}$ The two kings are named together

I9 The four Emar documents that refer to tribute payments were examined by Skaist (I998a, with references to earlier literature), who proposed identifying the key term arana as a Hurrian loanword meaning "tribute". Associating these four documents with another (Sigrist I993, no. 6) that refers to the presentation of four princesses of Emar along with a heavy payment to "the king of the land of Hurri", Skaist further proposed that "the king" who demands tribute was the king of Mittani (I998b, 62). While Skaist considered that the period of Emar's subordination to Mittani must have preceded the Hittite conquest of northern Syria in the mid-to-late I4th century (ibid.), Durand and Marti - who reinterpreted the text Sigrist I993 no. 6 and identified the payment accompanying the princesses as their dowries (2003, I45-I49) - dated this incident and the tribute payments to the early I3th century instead (ibid., I56-I58). Now, reanalyzing the evidence for the chronology of Late Bronze Age Emar and its archives, Cohen and d'Alfonso (2008) argue for the higher dating, placing Emar's tribute payments to Mittani before even the reign of Suppiluliuma I (see esp. $20 \mathrm{f}$. and Table 7). Writing in the same volume, Pruszinsky 2008,77 likewise places these episodes prior to the Hittite conquest of Emar and Aštata, but prefers the date "before Mursili's gth year".

20 It has been suggested that a tablet from Alalakh, AlT 395, records tribute owed to Mittani (see Wiseman I953, I4. IO4), but it contains no reference to Mittani and may instead be a record of internal revenue: the text lists quantities of silver (due) from three regions within the domain of Alalakh, namely Zalhe, Amahe (?), and its core territory, Mukiš (see von Dassow 2008, 55).

2 I For example, the narrative of Thutmose III's first campaign in his annals refers to the support of Naharin and allied lands for the coalition assembled at Megiddo, while the general description of his Syrian campaigns in the Gebel Barkal stela refers to the "numerous armies" of Mittani (for translations of both texts, see Hoffmeier 2000, 7-I8). Such references tend to be imprecise, creating an impression of incoherence on the part of Egypt's opponents.

22 These tablets are discussed by Rouault (2001, Io and 2004, 56 f.), as well as by Charpin (2002, 78). The legend of Qīš-Addu's seal, given in transliteration by Charpin, identifies Qīš-Addu as "king of the land [of Hana]". The tablets mentioned in these publications that record the king of Mittani alongside Q arranged according to the (putative) sequence of Mittanian kings: 
with a selection of gods in oath formulae and, apparently, as the joint sellers of town lands. The local king attested in these documents, Qǐš-Addu, is named alongside three different Mittanian kings, Saitarna, Parrattarna, and Sausadatra; the last is a variant spelling of the name Sauštatar, and the first has been tentatively identified as a variant of Suttarna, the name of Parrattarna's predecessor. Whether or not that identification is correct, Qǐš-Addu's reign evidently lasted through a succession of three kings on the throne of Mittani during the I5th century. Moreover, the relationship in which he and the king of Mittani appear as joint sovereigns at Terqa also endured over the same period. The information available hardly suffices to guess at the nature of this relationship or the underlying governance structure, which may recapitulate a model previously employed at Terqa. ${ }^{23}$ Nonetheless the apparent co-rulership of local and superordinate king seems to represent a different structure for integrating local polities into the empire than that implemented in kingdoms like Alalakh and Arraphe.

The two tablets found at Tall Bazi, which, on the basis of their contents, has been identified as ancient Bașiru (a place otherwise unknown to date), attest Mittani's relationship with a polity that was not structured as a monarchy. ${ }^{24}$ One tablet records Sauštatar's grant of a town, Baidali, to the people of Bașinu (DUMU.MEŠ uru Pa-zi-ri); Sauštatar sealed it with his own seal. The other tablet also records the grant of a town to the people of Basīru by a king of Mittani, this time Artatama (I), who also sealed the tablet with Sauštatar's seal. The loss of the second tablet's upper right corner entails the loss of the name of the town that is the object of the grant, but the town is described in specific terms: “(The town) [GN], whose [... ] neighbor is (the town) Te?-ru-[ ... ] and (whose) [ ... ] neighbor is (the town) Te-ú-a-ab?-x-[ ... (in?)] the district of (the town) Halab, 25 Artatama has given to the people of (the town) Bașiru." In both transactions, the party with whom the king of Mittani dealt was not a subordinate king but the people of the town, constituted as a polity. Evidently Basīru did without a king, and its people relied instead on collective self-governance, which they would

\footnotetext{
Sa-i-tar-na (= Suttarna?)

TQ I2-I9

Parrattarna

Sausadatra (= Sauštatar)

TQ I2-9, IO, I5, and I6

TQ I2-6 (and others?)

The reading I $\mathrm{Sa}$-ú-sa-da-at-ra is provided by Charpin 2002, n. I2I.

23 So according to Rouault 200I, 9f., with n. 34 .

24 The Tall Bazi tablets are published in Sallaberger et al. 2006, with detailed discussion of their archaeological context, textual contents, seal impressions, and historical interpretation.

25 Sallaberger et al. $(2006,98)$ insist on taking halșu to mean "fortress", rather than "district", and they identify the town that is the object of the transaction as a "fortress of Halab", apparently taking hal-sí uru Hal-pa in 1. 6 as appositive to uru[GN] in l. I. This interpretation is hardly self-evident, however, and the fact that halsu is ostensibly written in the genitive case would seem to speak against it (since case declension appears to be functional in the language employed to write the document, so far as may be discerned given its limited extent and preservation). They further adduce the fact that Halab was governed by a halș ḩlu, "district governor", in support of identifying the granted town as a halșu, "fortress", within the land of Halab, which does not follow. On the function of the halṣuhlu, see immediately below (n. 26).
} 
have exercised through an assembly or other representative body. ${ }^{26}$ Mittani, moreover, could also do without their having a king, and without vesting an individual official (whether local leader or royal appointee) with authority over the polity; in other words, the empire was able to exercise hegemony through local collective-governance regimes, as well as through local monarchs.

A different model was instituted in the case of Halab, erstwhile the seat of a great kingdom. Rather than permit Halab to remain under the rule of its own king, who would no doubt attempt to recover the realm's autonomy and former power, Mittani transformed it into a district, halsu, governed by a district governor, halzogili. ${ }^{27}$ The implementation of this strategy appears to have begun with Mittani's seizure of Halab and the consequent flight of its royal family in the time of Ilimilimma, father of Idrimi (around I500); this would be the event politely referred to as a mašiktu, "misfortune", in the inscription of Idrimi. Thanks to Mittani's success, Idrimi, having set out to recover his patrimony, in the end had to settle for a domain comprising some of Halab's former possessions but not Halab itself. ${ }^{28} \mathrm{Halab}$ was instead placed under the authority of a halzogli, as attested by AlT IoI, which dates to the reign of Idrimi's successor Niqmepa. AlT IOI records the extradition of fugitives from Halab in the presence of Niqmepa, an act that was witnessed by Arnuwar, halzogli of Halab. ${ }^{29}$ Arnuwar would have obtained this office through appointment by the king of Mittani. Subsequently, when Tudhaliya (I) was king of Hatti, a king ruled Halab again, according to the prologue of the Aleppo Treaty (KBo I 6), which says that the king of Halab first made peace with Tudhaliya (thus committing treachery against Mittani) but then turned around and made peace with the king of Hanigalbat (thus committing treachery against

26 Considering the textual evidence in conjunction with the tablets' findspot, and in light of the prevalence of collective government in the region of the middle Euphrates, Sallaberger et al. $(2006$, 93f.) even propose that the monumental building in which the two tablets were found served as the place of assembly for the elders of Basiin in effect, the senate building.

27 On the office denoted by the Hurrian term halzogili (Akkadian halșuhlu), formed from Akkadian halsu by the addition of the compound suffix -oğli (>-o-g(e)-li; Wilhelm I992), see Márquez Rowe (I997, I93-94), who examines this term in the context of his analysis of AlT IoI, discussed immediately below. Márquez Rowe observes that the Hurro-Hittite bilingual text KBo 32, I4 gives the Hittite equivalent of halzoğli as auriyaš išhaš, an official whose function was more or less that of a provincial governor, and further, that the responsibilities attested for the hal$z o g i l$ accord with this understanding of the term, as does the fact that the halzogli answered directly to the king. This is so in HSS IX I, discussed above (p. I7), in which the king of Mittani informs the king of Arraphe that he has directed the halzogli of a certain town to implement the territorial reallocation (within Arraphe) that he has ordered. The conclusion reached by Maidman (I98I, 240), based on examining the attestations in the Nuzi texts, that the halsuhlu was merely "a minor real estate official" represents too narrow an interpretation of the evidence. 28 For analysis of the relevant parts of the Idrimi inscription, the only source that refers (albeit obliquely) to the Mittanian takeover of Halab, see von Dassow 2008, I9. 24f. and 42-45.

29 On AlT IoI, see von Dassow 2008, $56 \mathrm{f}$. (with references to previous literature). Whereas my discussion there tacitly assumes that Halab had its own king during the period under discussion (when Sauštatar ruled Mittani and Niqmepa ruled Alalakh), the evidence does not really warrant that assumption. One of the tablets from Ekalte (no. 28) is dated by an apparently non-local official named Arnuwar, son of Šuliya, whom Mayer (200I, 24) suggests is the mayor (hazannu) of Emar, although the text does not indicate what office he holds. It is not inconceivable that he was the same man as Arnuwar the halzoggli of Halab known from AlT ıor. 
Hatti), wherefore Tudhaliya destroyed Halab and its king (around I400). ${ }^{\circ}$ Thereafter, under the rule of Artatama, Halab was again the seat of a district, halșu, not of a kingdom, as attested by the later of the two Tall Bazi tablets (see above, with n. 24).

Thus Mittani made Halab into a province, unlike other polities that it subjected, replacing the native regime with - as it seems - an administrative regime installed by the overlord. Indeed, resentment of this arrangement could account for Halab's decision to ally with Hatti when Tudhaliya showed up. Although the construction offered here rests on scant bits of evidence that, singly or in combination, do not exclude alternative scenarios, its validity may be supported by observing the care Hatti later took, when reestablishing kingship at Halab through the Aleppo Treaty, to prevent the Hittite viceroy from getting any ideas about independent kingship. The treaty's prologue underpins the new relationship between Hatti and Halab by reference to Hattusili I's defeat of Halab three centuries earlier: this act is construed as the moment when Hatti ended Halab's "great kingship", and on that premise - ignoring Mittani's conquest of Halab after its destruction by Mursili I - Halab is represented as "sinning” against Hattusili I, the city's original conqueror, in any subsequent relations with Mittani (Hanigalbat). This version of history was constructed to serve the goal of ensuring that Halab, though it had a king again, would remain subordinate to Hatti.

The foregoing discussion identifies three models employed by Mittani in governing its empire, in very general terms: first, a subordinate state could be ruled by its own king, whose fealty to his sovereign rendered the relationship between polities as a relationship between two men; second, a state could be self-governed, so that the relationship was between the collective body politic and the sovereign; third, the state could be subordinated to the point of incorporation as a province, annulling its political relationship to the sovereign

30 The passage paraphrased above is KBo I 6:I5-20. My understanding of the treaty prologue, and of these lines in particular, differs subtly from that of most scholars, especially on two points: a) I do not understand each successive statement to represent a chronologically successive event, rather, I understand the succession of statements in the prologue to loop back repeatedly to the "original" event whereby Hattusili removed Halab's "great kingship" (hence the prologue offers no basis for positing a Hattusili II); b) accordingly, I do not read each statement as representing a distinct event, rather, I understand certain events to be represented by several (not necessarily contiguous) statements apiece. The passage in question tells us the following: "When Tudhaliya, great king, ascended the throne of [kingship], the king of Halab made peace with him, but then the king of Halab turned around and settled with the king of Hanigalbat. And because of this deed, he (= Tudhaliya) smote them, the king of Halab and the king of Hanigalbat, toge[ther with their lands?], and he tore down the city of Halab" (11. I5-I8). The events thus described are then summed up with the evaluative statement "The king of Halab committed a sin [against] the king of Hanigalbat" (1. I9) - by his perfidious alliance with Tudhaliya - "and against Hattusili, [king of] Hatti, he committed a sin" (1. 20) - by then returning to the Mittanian fold; for any defection of Halab from Hatti was accounted a sin against Hattusili I, the original conqueror of Halab and founder of the Hittite kingdom. A thorough study of the entire treaty prologue, and a reconstruction of the sequence of events represented in it, must await another occasion; for the nonce, see Astour's exposition of the issue, in which he notes the text's use of "retrospective recapitulation," not uncommon in Hittite historical narrative (Astour I989, 4Iff., with references; meanwhile, the conventional misunderstanding of the text, complete with the phantom Hattusili II, is represented by Bryce 2005, I40f.). 
by annulling its status as a polity. In a variation on the first (or perhaps the third) model, the local king might be associated with the sovereign as co-ruler of his state. In all of these models, Mittanian jurisdiction was interwoven with local jurisdiction, so that, for instance, the judicial systems of subject states and the superordinate state could cooperate in the resolution of legal disputes, and the disposition of territorial rights as well as citizenship rights (discussed in the next section) was subject to Mittanian authority.

The sporadic illumination provided by the sparse sources necessitates developing general hypotheses on the basis of as little as a single instance, which is methodologically unsatisfactory, for it forces conjecture to blend with inference. Quite aside from its partly conjectural nature, the picture drawn above is unsatisfactory in its lack of specifics. We cannot even say whether Mittani regularly required tribute from states it subjected; the two occasions of tribute payment attested at Emar may or may not represent standard requisitions. Clearly various requirements or orders were expected to be fulfilled, but it is impossible to tell whether the examples found in the extant sources - e.g., the "men going to Mittani" from the kingdom of Alalakh - represent ordinary or extraordinary activity. The sources from Arraphe attest the provisioning of Hanigalbatean military forces, Hanigalbatean officers in command of Arraphean forces, and troops from Hanigalbat operating in Arraphe, but these records all derive from the final phase of the surviving archives, the countdown to Mittani's loss of the realm. To extrapolate normal practice over the preceding 150 years from the activities of that period would require additional evidence. As noted earlier, Egyptian sources assure us that Mittani could call upon the military resources of its empire, but it was not the task of those sources to explain how Mittani went about it.

\section{Sociopolitical organization}

Another way to inquire how Mittani and its constituent polities were organized is to approach the subject from the standpoint of the structure of the population, rather than the structure of government. Sources from different parts of the Mittani Empire yield the earliest direct evidence for class formation, as well as the earliest formal articulation of the concept of citizenship as the relationship of an individual to a given state. This is not to say that class differentiation and the idea of citizenship were previously nonexistent, but to highlight their explicit formulation in written records that were produced under the specific historical conditions of Mittanian rule, with a view to achieving better understanding of what those conditions were. 


\subsection{Citizenship}

Three documents, one apiece from three different places, concern the "Hanigalbatean status", hanigalbatūtu in Akkadian, of particular persons. In chronological order, these are as follows: one from Alalakh dating to the reign of Sauštatar (AlT I3, mentioned above); one from Umm el-Marra dating to the reign of Šuttarna II (UEM TI); and one from Tall Brak, within Mittani's core territory, dating to the reign of Tušratta (TB 800I). ${ }^{31}$ Although, among the numerous references to Hanigalbateans in sources from Arraphe (meaning primarily the archives found at Nuzi), none specifically concerns the status of "Hanigalbatean", at least two documents do concern property rights or obligations that are contingent on residence in Arraphe or in Hanigalbat; these documents are thus relevant to the issue of hanigalbatütu. Despite their small number, the geographical and chronological distribution of the sources pertaining to the "status of Hanigalbatean" is such that they may be understood to attest a general feature of the imperial polity, not a phenomenon peculiar to a certain region or moment.

AlT I3 records Sauštatar's decision of the case of one Irip-Hazi, who sued Niqmepa, king of Alalakh, claiming that he had Hanigalbatean status. His claim was denied, with the result that he had to return to the service of Niqmepa; that is, he was determined to be properly a subject of Alalakh and not of Hanigalbat. UEM TI records the elevation to Hanigalbatean status of a woman, her children, and a man, a change of status effected in the presence of Šuttarna by one Gubi, whose dependents or adoptees the beneficiaries evidently were (unfortunately the relationships linking the parties are unspecified); Gubi bequeaths part of his property to the man who is elevated to hanigalbatūtu (while also bequeathing personnel to another man, relationship unspecified). TB 800I similarly records one Yabbi's elevation of his concubine's son to Hanigalbatean status, concomitant with his bequest of property to that son, in the presence of Tušratta. In the case of both the Umm el-Marra and Tall Brak documents, the change of status is conjoined with the grant of family property: that is, the underlying transaction is the beneficiary's change of status from dependent, without property rights, to heir, with property rights. ${ }^{32}$ The benefactor could have accomplished this kind of transaction without involving the local authorities, much less going before the king of Mittani, but for the fact that the status to be conferred on his dependent(s) is that of "Hanigalbatean". For the beneficiaries to obtain this status, their benefactor must

3I On all three documents, see von Dassow 2008, 49-5I. For the edition of the Umm el-Marra tablet, with discussion of its archaeological context, sealing, and paleography as well as its textual content, see Cooper et al. 2005 . TB 800I, originally published by Illingworth I988, no. 23, with Pl. 9, is republished in Oates et al. I997, 4I, with Fig. 62. In the commentary accompanying his new edition of AlT I3, Niedorf also discusses the other two texts that feature the term hanigalbatūtu (Niedorf 2008, 24I-243).

32 Contra Cooper et al. 2005, 48-5I, the assumption that the beneficiary must have been enslaved prior to the benefactor's act is not logically (or legally) compulsory. Cf. also Giorgieri 2005, 8I-82. 
himself have had it, but he could not bestow it on a dependent other than his natural heirs without obtaining the king's assent.

In all three instances, the issue before the king was citizenship of Hanigalbat as distinct from either citizenship in a subordinate polity or lack of citizen status.33 In the case of Irip-Hazi, the king determined that he was not a citizen of Hanigalbat but of Alalakh; the denial of his claim of hanigalbatūtu meant that he was obliged to do labor and military service for the kingdom of Alalakh. ${ }^{34}$ In the case of Gubi's and Yabbi's adopted heirs, the king's consent to their acquisition of hanigalbatūtu meant that they would owe service to the kingdom of Hanigalbat and no other. Thus, whichever local polity's territory Umm el-Marra belonged to at the time, as "Hanigalbateans" Gubi's heirs would owe that polity no service. Instead, presumably Gubi's heirs could be levied for service to Hanigalbat, as could Yabbi's heirs, dwelling within Hanigalbat at Tall Brak. This concept of service being exclusive to the state of one's citizenship is borne out by the evidence of the census records and troop rosters from Alalakh: among the thousands of men enrolled on the extant tablets, dozens or perhaps hundreds are identified as natives of lands outside Alalakh's realm, but none is identified as a Hanigalbatean. 35

Meanwhile, citizenship entailed rights as well as duties: the Hanigalbatean citizenship that Irip-Hazi claimed, and that Gubi's and Yabbi's dependents acquired, meant that one enjoyed the legal protection of Hanigalbat. ${ }^{3}$ In the case of dependents adopted as heirs, elevation to hanigalbatūtu was necessarily accompanied by a bequest of family property, inasmuch as citizenship and the concomitant obligation to serve the state were contingent on having rights to property within the domain subject to that state.

It is this aspect that seems to be reflected, albeit obliquely, in two legal documents from Nuzi, JEN 328 and HSS XIX, 7. JEN 328 records the outcome of a legal process initiated by two sons of Tehip-tilla against one Šupa-hali, whose father, Arya, had sold his field to Tehiptilla, and who has not cultivated it. Šupa-hali, who has evidently been summoned from Hanigalbat, where he now resides, makes a declaration to the effect that the claimants shall

33 The distinction at issue is not between Hanigalbatean status and slavery; these were not the only two possible positions that a person within the Mittani Empire could occupy. The wardūtu to which Irip-Hazi must return in AlT I3 is subject-hood, not servitude.

34 The census records and troop rosters from Alalakh may show that he was then called up for such service; see von Dassow 2008, 363. Whether or not it is the same Irip-Hazi who appears in the census records, no doubt it was to avoid service that the Irip-Hazi who lost his case in AlT I3 went before Sauštatar with his claim of hanigalbatūtu.

35 One man, however, a member of the haniahhe class, is identified as originating from Mittani (AlT I35: IO-I2). Men of foreign origin are found principally, but not exclusively, among the habiru troops of Alalakh, which stands to reason given the nature of the social category designated habiru; see von Dassow 2008, IO5-III (on habirū in general), and 20I-2I5 and 344-348 (on the habirū of Alalakh).

36 On citizenship as the status of the legally free subject of a ruler see Westbrook 2003, 36-38 (with reference to hanigalbatūtu). Westbrook's definition has to be extended to encompass citizenship of states that were not constituted as monarchies, like the polity of Bașīru (discussed above). 
take the field.37 In confirming Tehip-tilla's sons' title to the field, the judges state that because Supa-hali does not reside in the land of Arraphe, they have not required him to pay the išpiku (penalty for the yield) of the field. The logic appears to be that because Supa-hali has both lost rights to property in Arraphe (through his father's alienation of the field) and changed his place of residence to Hanigalbat, he no longer owes any duty on his family's former property in Arraphe. By forfeiting property, residence, and duties in Arraphe and moving to Hanigalbat, though he has not thereby become a "Hanigalbatean", he has effectively ceased to be a citizen of Arraphe. The converse situation is perhaps in evidence in HSS I9, 7, the testament of Ilaya, son of Hapira, a Hanigalbatean residing in Arraphe where he commanded military forces..$^{8}$ After a series of stipulations on behalf of his wife, two sons, and a daughter, Ilaya declares that his two other sons, Zike and Tamartae, "live in another land" and shall have no right to any of his property; the property of Ilaya is, implicitly, located in Arraphe, and the land in which the excluded sons live is likely Hanigalbat.39 If so, while their family has changed residence and acquired property rights in Arraphe, Zike and Tamartae have remained citizens of Hanigalbat, wherefore they forgo sharing rights to the family's Arraphean property. Ilaya need not have lost the status of Hanigalbatean upon taking up residence and serving as an officer in Arraphe, but the sons who did not join him there were excluded from acquiring citizenship in Arraphe.

In the foregoing discussion, I read the sources to indicate a conceptualization of citizenship as an exclusive bond between the individual and the state, a relationship in which duties were conjoined with rights to property within the state, and one that was normally grounded in residence within the state's territory. $4^{\circ}$ This conceptualization was not new in the time of the Mittani Empire. The innovation, if it was indeed such, was to add a dimension to citizenship in the superordinate polity, Hanigalbat, now that it ruled a number of subordinate polities of differing structure across a broad territory. Citizenship in any of the subordinate polities remained exclusive and correlated with residence: one could not be a citizen of, for example, both Arraphe and Kizzuwatna, and one's duty to one state or the other depended on which state one's home town was part of. ${ }^{4}$ Citizenship in the superordinate polity, on the other hand, could be held by persons residing anywhere in the empire, from Arraphe to Alalakh, but they still owed service only to Hanigalbat. Because hanigalba-

37 The laconic rendition of Šupa-hali's statement in 1l. I3-16 is not wholly unambiguous, but he begins by noting that he resides in Hanigalbat and concludes by saying "they shall take" the field (reading i-le-qú-[šs $u$-mi at the end of 1. I6 bis; cf. Zaccagnini I979, 9, with n. 3I).

38 See Zaccagnini I979, IIf., 20.

39 As suggested by Zaccagnini I979, I2, whose puzzlement at Zike and Tamartae's exclusion from inheritance might be resolved by the interpretation offered here.

40 So in the case of territorial states; the terms need some adjustment to suit polities constituted of mobile populations.

4I This is illustrated by AlT I4, the record of Sauštatar's decision of the dispute between Alalakh and Kizzuwatna over the town of Alawari. The king of Mittani decided in Alalakh's favor, and Alawari was subject to conscription and other imposts by Alalakh (see von Dassow 2008, 48f., 51, and 362 f., with cross-references there). 
$t \bar{t} t u$ was geographically extensible, yet it carried exemption from service to subordinate polities, acquisition of this status was regulated by the Mittanian king.

Probably citizenship of Hanigalbat was more desirable than citizenship in one of the subject kingdoms. But it was apparently not exemption from military service that made it so. Hanigalbateans like Ilaya, son of Hapira (mentioned above), did a lot of the fighting in Arraphe when it became necessary to defend that kingdom - in the end unsuccessfully against Assyrian attack. ${ }^{42}$ Although the evidence pertaining to that particular historical moment cannot be extrapolated to the Mittani Empire in general, if it is at all representative, apparently the people who enjoyed Hanigalbatean citizenship did not fail to pull their own and their kingdom's weight.

\subsection{Class formation}

The explicit systems of social classes that are documented in kingdoms subject to Mittani owe their creation and implementation to deliberate Mittanian policy, rather than representing the outcome of an organic development. I have argued for this proposition in my study of the social class system attested in I5th-century Alalakh, comparing it to that attested in I4th-century Arraphe; here I review the evidence and the argument. 43

The archives of both Alalakh and Arraphe contain administrative records that categorize citizens of the realm according to four distinct classes. Each of the classes can be found in name or in substance elsewhere, both within and outside the Mittani Empire, but similar records documenting a quadripartite division of classes have not so far been found anywhere else. Although two instances of a phenomenon constitute a slender basis for positing a general rule, it cannot be the result of coincidence that Alalakh and Arraphe, lying on opposite sides of the empire, possessed class systems that were essentially identical in structure. The classes they distinguished are as follows:

- The main body of the free population comprised citizens who possessed rights to property and owed the corresponding duties of military and labor service. The general term for the service obligation was ilku, and accordingly this class was denoted ālik ilki, "doers of ilku-service", in Arraphe. In Alalakh, the same class was denoted by the Hurrian equivalent of ālik ilki, to wit, unuššg $l i$, formed of unǔšse (= ilku) with the composite oc-

42 Hanigalbatean involvement in the defense of Arraphe is discussed in some detail by Zaccagnini I979, esp. 20-25; see now Maidman 20IO, I5-I9. While Zaccagnini and others have understood the sources to indicate that Arraphe also came under Babylonian attack, Maidman finds that the evidence fails to support that interpretation.

43 At the conclusion of my study of the social classes of Alalakh and their historical development, I compare the Alalakhian and Arraphean systems of classes and set forth the hypothesis that these systems were created at the instance of the Mittanian ruling authority (von Dassow 2008, 35I-36I). The evidence from Arraphe derives primarily from a set of military census records found at Kirkuk (supplemented by a few records from Nuzi), on which see von Dassow 2009. 
cupational suffix -oğli, thus "unušš-service-man”. The usual term for this class, however, at Alalakh and elsewhere, was the common Semitic word hupšu, for which the Alalakh texts also employ an Akkadian synonym, șābū namê ("people of the countryside", "peasant"). When they were levied for war, members of this class fought as foot soldiers.

- Elevated above the general body of the citizenry was the nobility, who had the privilege of fighting from horse-drawn chariots rather than on foot. In most parts of the Mittani Empire, the nobility were dignified with a special designation, maryanni, which was formed by adding the Hurrian derivational suffix -nni to the borrowed Indo-Aryan word márya, “(young) man”. In Arraphe, the same class was instead denoted by the Akkadian designation rākib narkabti, "chariot rider". It bears emphasizing that the term maryanni has nothing to do with chariotry; etymologically, the word simply means "man", although as a modified loanword it was semantically transparent to no one. As such, maryanni was used to denote a special class of man, the nobility. Because the most distinctive feature of this class was the use of chariots in war, the term for it eventually acquired the connotation "chariot warrior", as its use spread beyond Mittani. Besides having the privilege of fighting in the chariotry, members of the noble class were exempt from labor service, and some evidence may indicate that they also enjoyed immunity from distraint for debt. The entry of new members into this class was accordingly regulated by local rulers, 44 in the same way as the acquisition of Hanigalbatean citizenship was regulated by the Mittanian ruler.

- At the lower end of the social scale, a class of impoverished citizens was differentiated from the main body of the service-owing, property-holding citizenry. In Arraphe, this class was denoted by the term $a \check{s} s \bar{a} b u$, "tenant", while in Alalakh it was denoted by various designations meaning "poor" (haniahhe, a Hurrianized West Semitic word,

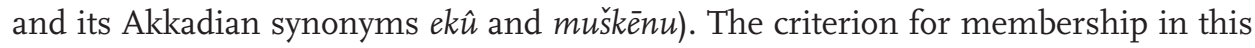
class appears to have been loss of rights to property in land, a circumstance that the state could reverse, as it may have done for "poor" citizens who continued to perform their service obligations. That members of the "poor" or "tenant" class did military service is evident from the records of both Arraphe and Alalakh. Therefore, the fact that they were categorically distinguished from the class denoted unuššogli or alik ilki apparently does not indicate that they were exempt from ilku or unǔšse.

- A fourth class was also differentiated from the rest, one that comprised occupational specialists and persons in the employ of the palace, temple, or high-ranking individuals. In Arraphe this class was denoted by the Hurrian term nakkošše, from the root nakk-, "release"; in Alalakh it was denoted by Hurrian egelli, from ehl-, "save", or by its Akkadian equivalent $\check{s} \bar{u} z u b u$, "saved, rescued". The terminology suggests that this

44 At Alalakh, this is attested by AlT I5, which records a royal grant of maryanni status, and AlT 9I, which establishes the maryanni status of a woman and her offspring (see von Dassow 2008, 272-279); no comparable document is known from Arraphe. 
class may originally have been formed of persons who were "saved" or "released" from debt servitude by a redeemer who thereby became their patron or employer. 45 If members of this class were beneficiaries of redemption, they did not, however, remain in servitude to their creditor, for they were subject to military conscription as free men. The denotations "released", "rescued" might also refer to the exemption of this class from labor service; its members appear to have been levied to contribute specialized labor (e.g., carpentry, metallurgy, training horses, or driving chariots) instead. Since the labor of debtors who practiced specialized trades would have had high value, and since the state had an interest both in requisitioning specialized labor and in maximizing the body of citizens subject to conscription, it is reasonable to suppose that the state used redemption from debt as an instrument for creating a class of occupational specialists. If this was the mechanism through which the class was initially created, however, it would appear to have accrued additional members not only through further redemptions, but through selecting persons having desired skills from the main body of the citizenry and the "poor" class, and reclassifying them into the "saved" class, which carried the benefit of release from regular labor service. ${ }^{46}$ By either means, the development of a distinct class of occupational specialists transpired at the state's initiative and under its ongoing regulation.

The foregoing description brings out the role of the state in defining these classes and their membership. The evidence from Alalakh indicates, furthermore, that the maryanni class of that kingdom was created during the course of Niqmepa's reign, by selecting the sons of noble families to constitute the new class. 47 The records we have do not attest a fixed structure that was simply imprinted on clay through the styli of the scribes who wrote them, but

45 I rejected this idea in my book (von Dassow 2008, 99, with cross-references), where I argued in essence that the egelli class was constituted by selecting persons on the basis of their trades, or their employment in the service of institutions or high-ranking individuals, and exempting them from regular labor service in order to obtain their specialized services. However, I am now persuaded by Márquez Rowe's argument that redemption from debt was a primary mechanism for creating this class (Rowe 2002, esp. 13-16), excepting his infelicitous expression of the relationship of patron to client, or employer to employee, as "ownership". My counter-arguments against the hypothesis that in the kingdom of Alalakh the entire ghelli class was constituted of persons redeemed from antichretic servitude remain valid. However, considering the terminology, the social realities that are its likely referents, and the general characteristics of the ghelli class, it appears that a combination of his hypothesis and mine would best account for the totality of the evidence available.

In this context, it may bear repeating that the fact that some members of classes other than ghelli (or nakkošse) are attested holding occupations, or being employed in the service of an institution or individual, does not invalidate the statement that the ghelli class, in aggregate, is distinguished by these characteristics (von Dassow 2008, 264, with n. 3I, and 3I5).

46 This proposition is supported by the evidence that the ghelli class doubled in size, as a percentage of the population subject to census, during the course of Niqmepa's reign at Alalakh (von Dassow 2008, 3I8). No diachronic evidence is available for the size of the nakkošse class in the kingdom of Arraphe, where we only have a snapshot of the quantitative relationship among the classes from the last phase of Mittanian rule.

47 See von Dassow 2008, 269. 
rather a process of class formation that was directed by the administration employing those scribes. Indeed, the scribes who conducted the census, enrolled men for service, or recorded their lands were enacting the state's role in organizing its citizenry into classes.

It is in that process and the mechanisms of its implementation, rather than in the occasional borrowed term (such as maryanni), that Mittani's hand is evident. If my interpretation of the material from Alalakh and Arraphe is right, instances of a comparable quadripartite class structure should be found in other polities subject to Mittani, if ever their archives are found and comparable types of records are preserved therein.

This paper represents an effort to work backward from observable phenomena to posit the invisible processes and structures that generated them. It is not a matter of stitching together bits of information extracted from the sources, and filling in the gaps; in the case of Mittani the sources remain too scant to apply such a procedure anyway, as is nowhere more obvious than in the ongoing uncertainty over the kingdom's chronology prior to the Amarna period. But the methods of inference implemented here should, if rightly employed, produce valid results regardless of whether the sources are many or few. And if so, perhaps some aspects of the structure of the Mittani Empire, and its relations with the polities and populations under its sway, have come into view.

\section{Bibliography}

\section{Anthony 2007}

D. Anthony, The Horse, the Wheel, and Language: How Bronze-Age Riders from the Eurasian Steppes Shaped the Modern World (Princeton 2007).

\section{Astour 1989}

M. Astour, Hittite History and Absolute Chronology of the Bronze Age. Studies in Mediterranean Archaeology and Literature, Pocket-book 73 (Partille i989).

\section{Bryce 2005}

T. Bryce, The Kingdom of the Hittites, 2nd ed. (Oxford 2005).

\section{Casana 2009}

J. Casana, Alalakh and the Archaeological Landscape of Mukish: The Political Geography and Population of a Late Bronze Age Kingdom, BASOR 353, 2009, 7-37.

\section{Charpin 2002}

D. Charpin, Chroniques du Moyen-Euphrate, I. Le 'Royaume de Hana': Textes et histoire, RA 96, 2002, 6I-92.

\section{Cohen - d'Alfonso 2008}

Y. Cohen - L. d'Alfonso, The Duration of the Emar Archives and the Relative and Absolute Chronology of the City, in: L. d'Alfonso - Y. Cohen - D. Sürenhagen (eds.), The City of Emar among the Late Bronze Age Empires: History, Landscape, and Society, AOAT 349 (Münster 2008) 3-25. 


\section{Cooper et al. 2005}

J. Cooper - G. Schwartz - R. Westbrook, A Mittani-Era Tablet from Umm el-Marra, in: D. I. Owen - G. Wilhelm (eds.), General Studies and Excavations at Nuzi II/I, Studies on the Civilization and Culture of Nuzi and the Hurrians I5 (Bethesda 2005) 4I-56.

\section{von Dassow 2008}

E. von Dassow, State and Society in the Late Bronze Age: Alalah under the Mittani Empire, Studies on the Civilization and Culture of Nuzi and the Hurrians I7, ed. David I. Owen and Gernot Wilhelm (Bethesda 2008).

\section{von Dassow 2009}

E. von Dassow, Sealed Troop Rosters from the City of Arraphe, in: Gernot Wilhelm (ed.), General Studies and Excavations at Nuzi II/2, SCCNH I8 (Bethesda 2009) 605-636.

\section{Drower 1973}

M. S. Drower, Syria c. I550-I400 BC, in: I. E. S. Edwards et al. (eds.), The Cambridge Ancient History, 3rd ed., vol. II, Part I: The Middle East and the Aegean Region c. I800-I380 BC, Chapter X (Cambridge I973).

\section{Fink 2007}

A. Sumaka'i Fink, Where Was the Statue of Idrimi Actually Found?, UF 39, 2007, I6I-245.

\section{Fink 20I0}

A. Sumaka'i Fink, Late Bronze Age Tell Atchana (Alalakh): Stratigraphy, chronology, history. British Archaeological Reports International Series 2I20 (Oxford 20IO).

\section{Giorgieri 2005}

M. Giorgieri, Bedeutung und Stellung der "mittanischen" Kultur im Rahmen der Kulturgeschichte Vorderasiens, in: D. Prechel (ed.), Motivation und Mechanismen des Kulturkontaktes in der späten Bronzezeit, Eothen I3 (Florence 2005) 77-IOI.

\section{Hoffmeier 2000}

J. K. Hoffmeier, Thutmose III., in: W. W. Hallo (ed.), The Context of Scripture, vol. 2: Monumental Inscriptions from the Biblical World (Leiden 2000) 7-I9.

\section{Illingworth 1988}

N. J. J. Illingworth, Inscriptions from Tell Brak I986, Iraq 50, I988, 87-Io8, with Pl. 9.

\section{Lion 2010}

B. Lion, Les fortifications de Nuzi d'après une tablette du Louvre, in: J. C. Fincke (ed.), Festschrift für Gernot Wilhelm anläßlich seines 65. Geburtstages (Dresden 2010) 203-216.

\section{Maidman I98I}

M. Maidman, The Office of halsuhlu in the Nuzi Texts, in: M. A. Morrison - D. I. Owen (eds.), Studies on the Civilization and Culture of Nuzi and the Hurrians (Winona Lake I98I) 233-246.

\section{Maidman 2010}

M. P. Maidman, Nuzi Texts and Their Uses as Historical Evidence, Writings from the Ancient World no. I8 (Atlanta 2010).

\section{Márquez Rowe 1997}

I. Márquez Rowe, Halab in the XVI ${ }^{\text {th }}$ and XV $\mathrm{V}^{\text {th }}$ Centuries B.C. A New Look at the Alalah Material, WZKM 87, I997, I77-205. 


\section{Márquez Rowe 1998}

I. Márquez Rowe, Notes on the Hurro-Akkadian of Alalah in the Mid-Second Millennium B.C.E., in: S. Izre'el - I. Singer - R. Zadok (eds.), Past Links: Studies in the Languages and Cultures of the Ancient Near East, IOS I8 (Winona Lake I998) 63-78.

\section{Márquez Rowe 2002}

I. Márquez Rowe, The King's Men in Ugarit and Society in Late Bronze Age Syria, JESHO 45, 2002, I-I9.

\section{Mayer 200I}

W. Mayer, Tall Munbāqa-Ekalte II. Die Texte, WVDOG Io2 (Saarbrücken 20oI).

\section{Niedorf 1998}

Ch. Niedorf, Die Toponyme der Texte aus Alalah IV, UF 30, I998, 515-568.

\section{Niedorf 1999}

Ch. Niedorf, Noch einmal zu den Toponymen der Texte aus Alalah IV, UF 3I, I999, 889-893.

\section{Niedorf 2008}

Ch. Niedorf, Die mittelbabylonischen Rechtsurkunden aus Alalah (Schicht IV), AOAT 352 (Münster 2008).

\section{Oates et al. 1997}

D. Oates - J. Oates - H. McDonald, Excavations at Tell Brak, vol. I: The Mitanni and Old Babylonian Periods (Cambridge I997).

\section{Pruzsinszky 2008}

R. Pruzsinszky, Bemerkungen zu institutionellen Veränderungen in Emar in der Spätbronzezeit in: L. d'Alfonso - Y. Cohen - D. Sürenhagen (eds.), The City of Emar among the Late Bronze Age Empires: History, Landscape, and Society, AOAT 349 (Münster 2008) 65-77.

\section{Raulwing 2000}

P. Raulwing, Horses, Chariots, and Indo-Europeans. Foundations and Methods of Chariotry Research from the Viewpoint of Comparative Indo-European Linguistics, Archaeolingua Series Minor I3 (Budapest 2000).

\section{Rouault 200I}

O. Rouault, Terqa et sa region (Ge-Ier millenaires av. J.-C.), Akkadica I22, 200I, I-26.

\section{Rouault 2004}

O. Rouault, Chronological Problems Concerning the Middle Euphrates during the Bronze Age, in: H. Hunger - R. Pruzsinszky (eds.), Mesopotamian Dark Ages Revisited (Vienna 2004) 5I-59.

\section{Sallaberger 2006}

W. Sallaberger - B. Einwag - A. Otto, Schenkungen von Mittani-Königen an die Einwohner von Bașīru, ZA 96, 2006, 69-I04.

\section{Sigrist 1993}

M. Sigrist, Seven Emar Tablets, in: A. F. Rainey (ed.), kinattūtu ša dārâti: Raphael Kutscher Memorial Volume (Tel Aviv I993) I65-I87. 


\section{Skaist I998a}

A. Skaist, A Hurrian Term at Emar, in: D. I. Owen - Gernot Wilhelm (eds.), General Studies and Excavations at Nuzi Io/2, SCCNH 9 (Bethesda I998) I69-I7I.

\section{Skaist $1998 \mathrm{~b}$}

A. Skaist, The Chronology of the Legal Texts from Emar, ZA 88, I998, 45-7I.

van Soldt 1995

W. van Soldt, Three Tablets from Tell Hammām et-Turkman, in: T. van den Hout - J. de Roos (eds.), Studia historiae ardens: Ancient Near Eastern Studies Presented to Philo H. J. Houwink ten Cate, PIHANS 74 (Leiden I995) 275-29I.

\section{Valério 20II}

M. Valério, Hani-Rabbat as the Semitic name of Mitanni, Journal of Language Relationship 6, 20II, I73-I83.

\section{Van De Mieroop 2007}

M. Van De Mieroop, A History of the Ancient Near East, 2nd ed. (Malden 2007).

\section{Westbrook 2003}

R. Westbrook, Introduction: The Character of Ancient Near Eastern Law, in: R. Westbrook (ed.), A History of Ancient Near Eastern Law, 2 vols. (Leiden 2003) I-92.

\section{Wilhelm 1992}

G. Wilhelm, Hurritische Berufsbezeichnungen auf -li, SMEA 29, I992, 239-244.

Wilhelm 200I

G. Wilhelm, Briefe aus Nuzi, in: B. Janowski - Gernot Wilhelm (eds.), Texte aus der Umwelt des Alten Testaments, Neue Folge, Bd. 3: Briefe (Gütersloh 200I) IOI-I05.

\section{Wiseman 1953}

D. J. Wiseman, The Alalakh Tablets (London I953).

\section{Zaccagnini 1979}

C. Zaccagnini, Les rapports entre Nuzi et Hanigalbat. Monographic Journals of the Near East, Assur 2/I, I979, I-26. 